\title{
O TESTEMUNHO SOBRE POLICIAIS: formas de produção de verdade na auditoria da justiça militar do estado do Rio de Janeiro ${ }^{1}$
}

\author{
LAW SUBJECT TO NORM: \\ juridical savoir and the process of normalization \\ in State Militay Justice audits
}

\author{
Sabrina Souza da Silva*
}

\section{Resumo}

O presente artigo procura realizar uma discussão sobre os processos e julgamentos na Auditoria da Justiça Militar do Estado do Rio de Janeiro e o papel das testemunhas de acusação nesses processos. As Auditorias Militares Estaduais são os locais com atribuição de processar e julgar crimes militares dos estados da Federação. Nesses espaços, as normas burocráticas que deveriam ser igualitárias são personalisticamente interpretadas, reinventadas ou esquecidas, em benefício de grupos ligados àqueles que têm poder. Nesse contexto, as relações organizadas hierarquicamente podem suplantar as próprias leis em vigor corroborando o lugar de cada um na estrutura hierarquizada das instituições militares. Assim, busco descrever como se dão asww tecnologias burocráticas nessa instituição.

Palavras-chave: Justiça Militar. Polícia Militar. Tradição inquisitorial. Testemunho.

\begin{abstract}
This article seeks to conduct a discussion about the processes and judgments in the Military Justice Audit of the State of Rio de Janeiro and the role of prosecution witnesses in these cases. State Military Audits are the places assigned to prosecute and to judge military crimes of the states of the federation. In these spaces the bureaucratic rules that should be egalitarian are personally interpreted, reinvented or forgotten for the benefit of groups linked to those who have power. In this context, hierarchically organized relationships can supersede the laws ruling, corroborating each other's place in the hierarchical structure of military institutions. Thus, I try to describe how the bureaucratic technologies in this institution.
\end{abstract}

Keywords: Military Justice. Military police. Inquisitorial tradition. Witness.

\footnotetext{
1 Uma primeira versão deste trabalho foi apresentada no XI Congreso Argentino de Antropología Social Rosario, 23 al 26 de Julio de 2014.

* Professora e pesquisadora da Universidade Federal Fluminense (UFF), Brasil. E-mail: ssouzadasilva@gmail.com
} 
O testemunho sobre policiais: formas de produção de verdade na auditoria da Justiça Militar do Estado do Rio de Janeiro

O presente artigo tem como objetivo fazer uma discussão sobre os processos e julgamentos na Auditoria da Justiça Militar do Estado do Rio de Janeiro (AJMERJ) e o papel das testemunhas de acusação nesses processos. Para tal fim, analiso dois casos $^{2}$ empíricos observados na auditoria supracitada: um de acusação de praças e um segundo em que um oficial é acusado. Assim, apresento ao leitor as diferenças hierárquicas existentes dentro do processo burocrático na instituição e a influência dessa hierarquia nas relações dentro da Polícia Militar do Estado do Rio de Janeiro (PMERJ) que resultam em uma denúncia.

Cabe destacar que, além das Auditorias Militares Estaduais, existem também as Auditorias Militares Federais, encarregadas de julgar militares do Exército, da Marinha e da Aeronáutica, mas que também podem julgar civis em casos de crimes militares. $^{3}$

O trabalho de pesquisa foi realizado durante os anos de 2009 e 2012, com algumas interrupções, e resultou na tese de Doutorado intitulada "Todos são culpados: uma etnografia da Auditoria de Justiça Militar do Estado do Rio de Janeiro" (SOUZA DA SILVA, 2013). A metodologia teve como base a observação direta, entrevistas com agentes do judiciário, policiais e bombeiros militares (juízes militares, réus, responsáveis pelos inquéritos ou que estavam desempenhando serviços burocráticos dentro da auditoria).

Para alcançar o objetivo proposto dividi o artigo em três partes distintas. $\mathrm{Na}$ primeira, descrevo como se realizam os processos na Auditoria de Justiça Militar do Estado do Rio de Janeiro, em seguida apresento e analiso o ritual jurídico realizado em uma audiência de acusação contra os dois praças da Polícia Militar e como é realizado um Inquérito Policial Militar (IPM), primeiro passo para a realização de uma denúncia na instituição jurídica citada. Em um terceiro momento, relato uma audiência de acusação de um oficial da Polícia Militar do Estado do Rio de Janeiro, analisando-a.

\section{A Auditoria da Justiça Militar do Estado do Rio de Janeiro}

A Auditoria da Justiça Militar do Estado do Rio de Janeiro tem como incumbência realizar os processo e julgamentos de militares estaduais, como já mencionado. Os julgamentos podem ser realizados de três formas diferentes: por

2 Chamo aqui de caso essas várias histórias descritas por mim, que interligam vários acontecimentos. Cabe destacar que caso também é uma categoria nativa entre juristas e jornalistas. Como chama a atenção Miranda (2008), a narrativa em forma de caso possibilita a construção de uma unidade artificial do problema, porém pode permitir que os agentes públicos mantenham a ideia de que o fato denunciado é uma prática excepcional, fruto de um comportamento desviante, armadilha na qual não queremos cair neste momento.

3 As denúncias ocorrem após uma investigação realizada pelos pares dos acusados, esses, por sua vez, deverão comparecer novamente perante o juiz-auditor e os juízes militares como testemunhas. Em anexo pode ser visto um gráfico que esclarece melhor o lugar das justiças militares estaduais dentro do judiciário. 
um juiz togado, chamado juiz-auditor, (para crimes que tenham vítimas civis); por um Conselho de Justiça Permanente (no caso dos praças da PMERJ), formado por oficiais da Polícia Militar que desempenham essa função durante três meses; por um juiz-auditor e por um Conselho Especial de Justiça (no caso de oficiais), formado por oficiais da PMERJ de patente superior ou mais antigos na corporação que o acusado (SOUZA DA SILVA, 2013).

As denúncias na auditoria serão realizadas pelo Ministério Público Militar (MPM) quando seus promotores forem convencidos da ocorrência de um crime previsto no Código Penal Militar - CPM (BRASIL, 1969).

O rito processual na auditoria inicia sua fase oral com o interrogatório do réu, que seria um meio de defesa e um meio de prova. Cabe lembrar que, no Brasil, não existe o crime de perjúrio, por esse motivo, o réu pode mentir em seu depoimento. Isso não ocorre no caso das testemunhas, que sempre poderão sofrer a ameaça de serem acusadas de falso-testemunho.

Após o interrogatório do réu, acontecerão as oitivas das testemunhas que normalmente ocorrem meses após a primeira audiência. Em um segundo momento, serão ouvidas as testemunhas de acusação. E, novamente, com um intervalo de meses, se ouvirá as testemunhas de defesa. Nessas oitivas, o juiz realiza perguntas ao interrogante e, depois das respostas, dita sua interpretação para o escrevente daquilo que foi interpretado por ele como resposta.

Por fim, ocorre a Audiência de Instrução e Julgamento (AIJ). Cada uma das partes (acusação e defesa) terá três horas para suas argumentações, nessa fase do processo, e uma hora de réplica e tréplica. Esse tempo estipulado dificilmente é utilizado pelas partes. Como o que impera no processo é a lógica do contraditório, cada argumento terá um contra-argumento e cada prova uma contraprova, pois essa lógica impõe uma instrumentalidade ao argumento. Dada a desigualdade legal e explícita, as decisões são daqueles que detêm o poder, fundado em um saber apropriado particularizadamente (KANT DE LIMA, 2011). A legitimidade nas decisões tomadas pelos juízes alicerçam esse saber particularizado, confirmando o poder daqueles que estão no topo da hierarquia.

\section{O caso Joana e Cláudio: os interstícios da rotina ${ }^{4}$}

Em abril de 2008, o casal Joana e Cláudio 5 foi abordado por dois policiais, que encontraram com eles algum tipo de erva seca. Os policiais militares que realizaram a abordagem chegaram à conclusão, pela aparência da erva, que se

\footnotetext{
4 A versão do caso narrado é a da denúncia realizada pelo Ministério Público Militar. Não tive acesso a outras versões da natureza do conflito, porém achei interessante trazer essa narrativa para o trabalho, mesmo sendo apenas a versão burocrática do conflito, para dar mais riqueza à análise do ritual jurídico na auditoria.

5 Todos os nomes utilizados neste texto são fictícios. No caso dos policiais e agentes da justiça, utilizo a patente e o cargo para uma clareza maior do lugar de cada um no contexto analisado.
} 
O testemunho sobre policiais: formas de produção de verdade na auditoria da Justiça Militar do Estado do Rio de Janeiro

tratava de maconha, um tipo de entorpecente que tem seu uso proibido no Brasil. ${ }^{6}$ Diante da conclusão de se tratar do porte de um produto ilegal, pediram ao casal uma quantia em dinheiro para liberá-los. Porém, o casal negou-se a pagar a quantia pedida e, assim, ficaram horas detidos (de forma ilegal) pelos dois policiais, em um Destacamento de Policiamento Ostensivo (DPO) localizado na zona norte da cidade de Niterói, região metropolitana do Rio de Janeiro.

Depois de algumas horas aprisionados, Joana e Cláudio decidiram entregar o dinheiro que dispunham e, com isso, foram liberados. Após o acontecido, com uma certa indignação, o casal decidiu procurar uma Delegacia da Polícia Civil para denunciar os dois policiais. Como na maioria dos casos envolvendo acusações contra policiais militares, o casal foi encaminhado à Delegacia de Polícia Judiciária Militar DPJM. Uma vez lá, eles conseguiram, finalmente, realizar a denúncia. ${ }^{7}$

As Delegacias de Polícia Militar Judiciária - DPJM - são submetidas à Corregedoria Interna da Polícia Militar do Estado do Rio de Janeiro, tendo como responsabilidade realizar investigações e Inquéritos Policiais Militares - IPMs - que tenham como acusados policiais e bombeiros militares. Atualmente, no Rio de Janeiro, existem oito DPJMs.

Somente funcionários militares estaduais têm competência para registrar crimes militares contra seus colegas de farda, sejam eles policiais ou bombeiros. Nesse sentido, o policial (ou bombeiro) que realiza um inquérito fica em uma posição paradoxal, pois, ao mesmo tempo em que tem a obrigatoriedade de investigar e produzir provas contra outro policial, estará trabalhando para incriminar um colega que compartilha da mesma "ética profissional” (KANT DE LIMA, 1995). O IPM é o primeiro passo para que um caso chegue à Auditoria de Justiça Militar do Estado do Rio de Janeiro. A seguir descreverei como, em teoria, deveria ser realizado um IPM.

\section{O Inquérito Policial Militar - IPM}

Um Inquérito Policial Militar, formalmente, é iniciado por uma portaria, documento emitido por um oficial militar. Pode ser instaurado por determinação de um superior, por pedido do Ministério Público, por requerimento da parte ofendida (caso convença um militar) etc. Durante a investigação, serão levantados antecedentes criminais, fichas funcionais, processos administrativos ou outros procedimentos que possam avaliar o caráter e o temperamento do acusado. Além disso, serão ouvidos

\footnotetext{
6 Para saber mais sobre a legislação sobre o porte de drogas no Brasil ver Lei 11.343 de 23 de agosto de 2006. http://www.planalto.gov.br/ccivil_03/_ato2004-2006/2006/lei/111343.htm consultado em 03/05/2012. 7 Certa vez, ao procurar uma delegacia para saber como os policiais civis encaminhavam alguns casos não previstos no Código Penal Militar - CPM - que é de 1969, todos os policiais repetiram que encaminhavam para a corregedoria. Porém, como nem todos os crimes previstos no Código Penal estão previstos também no CPM, em alguns casos, como tortura, por exemplo, crime equiparado a hediondo, se houver encaminhamento para corregedoria o enquadramento será por lesão corporal, que terá uma pena muito menor.
} 
indiciados, testemunhas, ofendidos. Também pode ser realizado o reconhecimento de pessoas, acareações, exame de corpo de delito (ou quaisquer outros exames periciais) que sirvam como provas capazes de dar apoio à decisão dos juízes.

Cumpre notar que a hierarquia militar e a confiança dos superiores em determinados policiais sempre nortearão a escolha daqueles agentes que se responsabilizarão por alguns inquéritos. O policial que ganha essa função é chamado de "encarregado". Nesse sentido, não será "qualquer policial" que terá como incumbência esse trabalho, apenas alguns, selecionados entre muitos.

Os encarregados por esses IPMs têm, entre outras responsabilidades, a atribuição de converter seus saberes práticos - e aquilo que suspeitam ser crime militar - para uma linguagem que possa ser operacionalizada no processo. $\mathrm{O}$ encerramento do IPM se dá com a produção de um relatório realizado pelo encarregado do inquérito, sempre um oficial de posto superior ao acusado. Esse documento é encaminhado ao Ministério Público Militar - MPM - que decidirá se realizará a denúncia.

Quando chega à auditoria, o caso já possui, portanto, uma versão e, nesse sentido, a sua verdade jurídica já começou a ser construída. As histórias contadas pelas vítimas, testemunhas e policiais envolvidos precisam ser transformadas em um relato impessoal, utilizando-se de procedimentos burocráticos e jurídicos (MIRANDA E PITA, 2011). A partir daí, ganha uma linguagem própria que busca fazer uma mediação entre o que seria a realidade e a descrição formal do acontecido.

Logo após a denúncia, a subordinação da versão policial perante o restante do sistema de justiça já começa a se apresentar. Os mesmo policiais realizadores do IPM continuam comparecendo à auditoria, todas as vezes que o juiz julgar necessário, para prestar seu testemunho e continuar na referida produção da verdade, porém, agora, com outro papel.

Os interrogatórios orais, que acontecerão se houver acusação, terão como base essa primeira versão autorizada do processo que deu elementos para a denúncia. Essa versão, lida todas as vezes que o acusado comparecer em juízo, será rebatida pela defesa e questionada pela acusação, podendo, nesse momento, apresentar possíveis incongruências (ou contradições) trazidas, através dos depoimentos orais, pelo réu e pelas testemunhas.

Em muitos casos, a versão produzida durante o inquérito é colocada sob suspeição, assim como todos os outros envolvidos no processo. Como a ação judiciária da polícia situa-se no plano inferior da hierarquia judicial, todos os indícios produzidos pela polícia devem ser reproduzidos perante o juiz (KANT DE LIMA, 2011).

\section{Audiência de acusação}

Dois anos depois da denúncia descrita acima, aconteceu a audiência de acusação do caso, na Auditoria de Justiça Militar do Estado do Rio de Janeiro. Os dois cabos da Polícia Militar, responsáveis pela ação, foram acusados pelo promotor do MPM pelo crime de "extorsão", como previsto no artigo 243 do Código Penal Militar (BRASIL, 1969). 
$\mathrm{Na}$ audiência, normalmente, aqueles policiais militares que realizaram o Inquérito Penal Militar são chamados para pronunciarem-se em juízo e são inquiridos, nesse momento, pelo juiz-auditor. Os juízes-auditores são juízes togados responsáveis pelas Auditorias de Justiça Militar, e seu vínculo institucional, no Rio de Janeiro, é com o Tribunal de Justiça do Estado. Assim, sua titularidade como auditor é temporária e muito influenciada por questões políticas, já que sua indicação é negociada politicamente.

O juiz-auditor citado inicia toda sessão que preside perguntando se o policial inquirido como testemunha confirma o que ele mesmo escreveu na acusação, registrada no IPM. No caso descrito acima, a testemunha, um tenente da PM, que havia participado da realização do IPM, afirmou que tinha realizado uma acareação, ${ }^{8}$ como de praxe, entre os denunciantes e os policiais. E acrescentou que os denunciantes (o casal) "atiravam para todos os lados", acusando os policiais da delegacia e, até mesmo, a então governadora, de corrupção. ${ }^{9} \mathrm{O}$ tenente complementou afirmando que o "próprio nacional", ${ }^{10}$ referindo-se ao denunciante, alegou ser "dependente em tratamento".

Frente à negativa da promotora e da defensora de inquirir a testemunha, a mesma assinou seu depoimento e se retirou para que a próxima testemunha de acusação entrasse na sala de audiência. ${ }^{11}$

A testemunha seguinte, também um policial responsável pelo inquérito, era um capitão da PM. Depois de lida a acusação e perguntado, pelo juiz, se confirmava os fatos, o capitão da PM repetiu toda a versão da testemunha anterior, dizendo que "as supostas vítimas atiravam para todos os lados" e complementou destacando as ótimas fichas que os dois policiais apresentavam em suas unidades, com comportamentos que variavam de "excepcional a bom". Além disso, ressaltou que seus depoimentos teriam sido tranquilos, o que o levava a pensar que, por isso, estariam falando a verdade. $\mathrm{O}$ interrogado fez questão de destacar que a postura dos policiais acusados era diferente das "supostas vítimas", "muito exaltadas", levando a que os policiais pedissem, várias vezes, que elas se acalmassem.

Por fim, com os depoimentos impressos e assinados pelas testemunhas, os acusados - que acompanharam todos os depoimentos - também o assinaram e se retiraram da sala. As vítimas-denunciantes ${ }^{12}$ não compareceram para dar seus

8 É uma técnica jurídica em que as partes confrontam-se, levantando-se os pontos divergentes, para que, supostamente, aqueles que solicitaram a acareação cheguem a alegações ou afirmações verdadeiras.

9 Corrupção é uma tipificação penal, tanto no CPM quanto no CP, porém é também usada no senso comum como categoria de acusação contra qualquer agente público por desvio de verba, por extorsão, concussão, entre outras. Como chama a atenção Nascimento (2017), é um conceito jurídico, mas também um conceito moral.

10 Essa é a forma tradicional dos policiais referirem-se a uma pessoa específica de nacionalidade brasileira. 11 As testemunhas são ouvidas sempre uma de cada vez, de modo que uma não ouve o testemunho da outra. Essa técnica busca possíveis contradições entre elas, conforme me afirmou certa vez um membro do Ministério Público.

12 Chamo de vítimas denunciantes aqueles que sofreram uma violação de direitos e decidiram denunciar tal violação. 
depoimentos. ${ }^{13}$ Por isso, as testemunhas de acusação foram apenas os policiais que realizaram o inquérito que corroboraram aquilo que escreveram no relatório, que deu fim ao inquérito e início à denúncia.

Vítimas-denunciantes não comparecerem em juízo não é tão incomum, no entanto, isso não significa que o processo será arquivado, como não foi no caso descrito acima, pois, após a denúncia, o processo passa a ser do Estado e não da vítima (SOUZA DA SILVA, 2017). O que normalmente acontece é que, mesmo as vítimas não comparecendo, os acusados são condenados, fato que se repete no caso descrito, fazendo com que os depoimentos das testemunhas isentando e elogiando os acusados não sejam importantes para convencer o juiz da inocência dos policiais, mas sim para corroborar as conclusões do inquérito realizado.

$\mathrm{Na}$ maioria dos casos observados, os policiais que realizaram o IPM eram as únicas testemunhas de acusação em todo o processo. Os responsáveis por um IPM são aqueles que têm a confiança do seu superior para exercer tal atividade, neste sentido, ter a responsabilidade de realizar o IPM é um privilégio.

Por outro lado, policiais que investigam seus próprios colegas não são muito bem vistos pela corporação. Lembro que acompanhei um curso de Especialização em Justiça Criminal e Segurança Pública, na Universidade Federal Fluminense ${ }^{14}$, e que, na época, a turma dividia-se em pequenos grupos, normalmente reproduzindo os grupos que já existiam dentro da polícia. Os policiais que estavam na corregedoria, antes de entrarem no curso, formavam um grupo apartado, que quase nunca "misturava-se" com o restante da turma. Em um outro momento, um policial que trabalhava no serviço reservado da PM, certa vez, em uma conversa informal, também afirmou-me que " $P 2^{15}$ não tem amigo" quando falava da possibilidade de alguém de seu batalhão testemunhar em sua defesa em um processo que respondia (BLANC JÚNIOR, 2017).

Assim, pelo lugar que ocupam no sistema de justiça criminal, hierarquicamente inferior, somado à desconfiança de que todo policial pode estar "no erro", apenas não foi pego, faz com que a participação desses policiais, como testemunhas, não seja muito confortável: quando o policial que fez o IPM vai depor, além de produzir mais provas, agora em juízo, contra o réu, vai também ter seu

13 Após a realização da denúncia, no Brasil, o Estado passa a ser dono do processo e a vítima, nesse sentido, passa a ser considerada apenas mais um envolvido.

14 Esse curso é iniciativa de professores e pesquisadores da Universidade Federal Fluminense (UFF) e de oficiais da Escola Superior de Polícia Militar do Estado do Rio de Janeiro (ESPM/RJ). Foi inicialmente financiado pela Fundação Ford, por meio de sua assessora à época, Dra. Elizabeth Leeds e, posteriormente, pelo Instituto de Segurança Pública da Secretaria de Segurança do Estado do Rio de Janeiro. Atualmente, é financiado pela Rede Nacional de Altos Estudos em Segurança Pública (RENAESP), da Secretaria Nacional de Segurança Pública (SENASP). O curso foi por muito tempo parte do Curso Superior de Polícia, por isso obrigatório para oficiais da Polícia Militar para a ascensão para postos mais elevados dentro da corporação.

15 P2 é o serviço reservado da Polícia Militar. Teoricamente, a responsabilidade dos policiais alocados como P2 é investigar os próprios colegas, no entanto, acabam, também, investigando civis. 
trabalho posto à prova. Nesse sentido, não só a verdade está em jogo, mas também a falsidade (GOODY, 1987) que pode estar escondida por trás de uma denúncia. É bom lembrar que além de falso-testemunho, ${ }^{16}$ denunciar falsamente alguém é um crime previsto no Código Penal Militar com a possibilidade do acusado ser condenado de 2 a 8 anos de reclusão.

Portanto, os policiais que fizeram o inquérito são invocados pelo Ministério Público para participar das audiências de acusação, mas, para além de apenas construir verdade sobre o acusado, precisam, também, provar que a acusação é legítima e não produto de uma injustiça causada por algum tipo de interesse particular dentro da corporação em que trabalham.

Segundo o Código de Processo Penal Militar (BRASIL, 1969), a testemunha não pode limitar seu depoimento à simples declaração de que confirma o que afirmou no inquérito ${ }^{17}$. Por isso, ela é obrigada a pronunciar-se em juízo. Mesmo que isso não seja sempre levado em conta, essa legislação - assim como a possibilidade de acusação de falso-testemunho - pode ser manipulada para acusarem testemunhas que decidam não falar perante o juiz.

Em muitos casos, em outras instituições judiciárias, policiais chamados a depor, ao testemunharem, dizem não lembrar o ocorrido ou, apenas, confirmam o que está no documento escrito (EILBAUM, 2008). Porém, na auditoria, dificilmente isso acontece. Mesmo que o policial não se lembre do inquérito que realizou, será perguntado sobre a conduta do acusado, como ele é em suas funções e sua personalidade, o que ocorre, principalmente, quando a testemunha e o réu trabalham na mesma unidade operacional, fato não muito incomum, já que, com a anuência do comandante da unidade, qualquer superior hierárquico pode instaurar um IPM.

Apenas em uma audiência, acompanhei uma tenente, encarregada de um IPM, ler e reler, por um longo tempo, seu relatório, enquanto todos os presentes esperavam. Ao ser perguntada se a assinatura no relatório era dela, a policial confirmava, porém dizia não lembrar de nada sobre o caso, bem como, não conhecer os réus. Por fim, a tenente resolveu confirmar o que havia escrito e assinar seu depoimento em juízo o que, naquele caso, foi aceito pelo juiz sem maiores consequências.

$\mathrm{Na}$ audiência descrita acima, aceitou-se que a tenente tivesse esquecido o que escreveu no inquérito que assinou, mesmo que, legalmente, esteja previsto que não é aceitável que isso ocorra. No entanto, esse tipo de tolerância na auditoria não ocorre sempre. Já acompanhei uma acareação, realizada em um caso de desvio de doações para vítimas de enchentes, em um Batalhão de Bombeiros Militares, em

16 Está previsto no Código de Processo Penal Militar que, quando presta seu depoimento, a testemunha deve dar sua palavra de honra de falar somente a verdade. No entanto, nunca vi esse compromisso sendo prestado verbalmente na auditoria, o que não nega ao juiz a responsabilidade, se perceber que a testemunha mentiu, de encaminhar uma cópia daquilo que achou ser indício de falso-testemunho à polícia, que instaurará um inquérito. Já a testemunha não é nem mesmo advertida do compromisso de dizer a verdade, mesmo podendo ser acusada de um crime.

17 Previsto no art. 352 do Código Penal Militar (Brasil, 1969). 
que os bombeiros, que fizeram o IPM, deram depoimentos discrepantes. Depois da audiência, com os militares estaduais que realizaram o inquérito sob suspeita, o juizauditor decidiu pedir que fosse realizado outro inquérito, dessa vez para investigar o suposto falso-testemunho por parte dos bombeiros que realizaram a investigação.

Acusar de falso-testemunho não é tão incomum assim: no período de janeiro de 2000 a junho de 2009, oito militares estaduais foram denunciados por esse crime. Por esse motivo, o que é dito em testemunho deve ser verossímil e, por isso, normalmente, os policiais que vão testemunhar repetem-se em suas argumentações. Mesmo sendo ouvidos em separado, dificilmente falam coisas muito discrepantes. Como muitos deles já conhecem os procedimentos, parecem ensaiar suas versões. Além disso, o policial deve saber apresentar-se, pois, assim como as suas palavras, seu corpo também estará construindo uma representação da confiabilidade do inquérito ou não. Nesse sentido, quando o policial, que realizou o inquérito, é chamado para testemunhar na auditoria, comparece naquele local de maneira solene, com sua farda limpa e bem passada, com seu coturno brilhando e uma corporalidade confiante, pois qualquer deslize pode acarretar uma acusação de falso-testemunho ou de falsa perícia. Nesse sentido, o corpo dos envolvidos fala (FOUCAULT, 2000; EILBAUM, 2010).

Essas testemunhas não se comunicam apenas por meio de palavras, elas usam uma postura específica na hora de prestar seu depoimento. Corpo ereto, mas olhar cabisbaixo, no caso dos praças, e corpo ereto e olhar direto para os juízes, no caso dos oficiais. Conhecer todas essas técnicas de uso do corpo, de que roupa colocar e que discurso fazer, não entra nos autos, mas tem uma eficácia nesse tipo de ritual, pois não deixa de ser uma forma de comunicação, uma linguagem (MAUSS, 1979). Tal linguagem é construída, principalmente, a partir da experiência, que permite que o corpo seja utilizado de maneira eficaz. Assim, além de o corpo ser uma forma de "ser e estar" também é uma forma de se apresentar. Com essa corporalidade, que se junta ao discurso, vai-se construindo a verdade que deverá entrar nos processos e, principalmente, a opinião e, posteriormente, o convencimento dos agentes da auditoria sobre os envolvidos. Porém, não é apenas isso que será levado em conta, pois a desconfiança de que todo policial pode estar errado, mesmo com todo esforço de uma boa apresentação, estará presente na perspectiva do juiz até sua decisão ${ }^{18}$.

Como no caso do sistema processual penal brasileiro, o sistema acusatório é mesclado com o sistema inquisitório (KANT DE LIMA, 2010; MENDES, 2012), as demonstrações escritas no inquérito precisam de um correlato oral verossímil. Assim, a verdade é produzida por um mecanismo de dois elementos: o do inquérito conduzido em segredo pela autoridade policial e o do ato realizado ritualmente pelo acusado e pelas testemunhas. Realizar um inquérito significa ter a confiança de um superior, mas, também, correr riscos, pois todos os envolvidos em um processo, em uma auditoria, são suspeitos. Nesse sentido, aquele que era digno de confiança durante o inquérito pode passar a ter a desconfiança daqueles que participarão do restante do processo.

18 O $7^{\circ}$ Anuário do Fórum Brasileiro de Segurança Pública, divulgado em 2013, destaca que 70,1\% dos brasileiros desconfiam da polícia. Essa desconfiança atinge diretamente a percepção dos juízes sobre esses agentes. 
Com a possibilidade de a legislação do Código Penal Militar ser manipulada para incriminar (ou não) policiais, as testemunhas, ao darem seus depoimentos em juízo, o fazem levando em conta os limites aceitos pelos agentes daquela justiça e não apenas as legislações prescrita em códigos e leis, adaptando seus testemunhos às formas aceitas naquele espaço.

\section{O caso do Major Oliveira: a auditoria e a política}

A primeira vez em que tive a oportunidade de acompanhar um processo em que um oficial superior foi acusado foi no caso do Major Oliveira da PM, incriminado por publicar, sem licença, "ato ou documento público ou de criticar publicamente ato de seu superior", crime militar previsto no artigo 166 do Código Penal Militar ${ }^{19}$ (BRASIL, 1969).

Major Oliveira havia publicado em seu blog, na Internet, um documento em que pedia que o chefe do Estado Maior, na época, fosse submetido a um Conselho de Justificação. Esse pedido se deu pelo oficial acreditar que o chefe do Estado Maior havia traído um compromisso assumido com seus companheiros de corporação. O compromisso manifestado havia sido com o denominado "Movimento dos Barbonos", liderado por coronéis full, patente mais alta da Polícia Militar do Rio de Janeiro, e que se formou a partir de 2006. Tinha como principal objetivo fazer uma série de reivindicações ao Governo do Estado do Rio de Janeiro para a melhoria da PMRJ. Tais reivindicações podem ser vistas na "Carta do Barbonos", publicada em diversos meios de comunicação da época (Carta ao Povo do Rio de Janeiro Coronéis Barbonos, 2008). Muitas das reivindicações da carta foram incorporadas à Proposta de Emenda à Constituição Federal (PEC 300), de $2008^{20}$.

Entre outras demandas, o projeto de emenda reivindica que a remuneração dos Policiais Militares dos Estados não seja inferior à da Polícia Militar do Distrito Federal, aplicando-se também aos integrantes do Corpo de Bombeiros Militar e aos inativos. O compromisso consistia em que nenhum oficial que assinou a carta (comprometendo-se com o movimento) assumiria cargo de comando após a exoneração de muitos oficiais feita pelo Secretário de Segurança, porém, esse oficial acabou aceitando o convite de ocupar um dos cargos de comando com maior poder dentro da corporação, traindo, assim, a causa do movimento.

O Inquérito Policial Militar ficou sob a responsabilidade de um tenentecoronel da PM de confiança do comandante. No relatório final, o encarregado pelo processo acabou concluindo pela culpabilidade do acusado e realizou a denúncia.

19 Publicar documento militar ou assemelhado, sem licença, ato ou documento oficial, ou criticar publicamente ato de seu superior ou assunto atinente à disciplina militar, ou a qualquer resolução do governo.

20 A Proposta de Emenda à Constituição foi elaborada pelo deputado Arnaldo Faria de Sá, do PTB de São Paulo. 
Acusa quem pode, cala quem tem juízo

Acompanhei a audiência de acusação alguns meses após a primeira audiência. Eu não havia observado o interrogatório do réu, por isso, acabei tomando conhecimento do caso nesse segundo momento do ritual jurídico. As testemunhas ouvidas foram o chefe do Estado Maior, responsável pela realização da denúncia, o comandante da Polícia Militar do Estado do Rio de Janeiro e o tenente-coronel que havia presidido o IPM.

O chefe do Estado Maior iniciou, então, seu testemunho, defendendo-se contra as alegações do acusado no pedido de inquérito que encaminhou a alguns superiores e publicou em seu blog. Para ele, o compromisso que havia firmado teria "caído por terra para o bem da hierarquia e da disciplina", pois ele não poderia deixar de atender a ordem de um superior para assumir um cargo de comando, já que deixar de obedecer à hierarquia e à disciplina desembocaria em uma "tendência para o caos".

Como chama a atenção Holloway (1997), a manutenção da disciplina militar na polícia do Rio de Janeiro, que incluía solidariedade corporativa e rígidas normas internas, foi apresentada como o melhor mecanismo de controle desses agentes quando a elite política decidiu contratar membros das classes livres inferiores como seus agentes de repressão, já que o problema era garantir que esses homens, uma vez armados, uniformizados e circulando pelas ruas, favorecessem, mais do que comprometessem, o objetivo geral da ordem e da tranquilidade pública. Porém, cabe destacar, que não é por acaso que a ideia de hierarquia vem antecedendo a de disciplina, nas legislações militares, já que ter disciplina significa mais do que a obediência às leis, reconhecer e respeitar as hierarquias dentro da instituição.

O comandante da PM foi a segunda testemunha a ser chamada. Manteve-se nessa mesma argumentação, dizendo que o acusado teria "quebrado os pilares da hierarquia e da disciplina", complementando que ele, como comandante, tem o dever de zelar por esses "pilares". Além disso, lembra que todos os policiais militares fazem o juramento de "seguir as autoridades constituídas, bem como as leis, tanto as da própria corporação, quanto as da nação."

O último a depor foi o coronel da PM responsável pelo IPM, que confirmou seu relatório, complementando que o que foi dito pelo réu na internet, "que o comandante e o chefe do Estado Maior eram indevidos de estarem no cargo", colocava em cheque os principais pilares da instituição militar.

Mesmo fazendo parte de um Conselho de Justiça, os juízes que estavam incumbidos de acompanhar o processo e julgar o réu não fizeram perguntas, ficando satisfeitos apenas com a argumentação das testemunhas perante a leitura da denúncia.

Como venho tentando demonstrar, a desconfiança, tendo como base o lugar hierárquico que aquele que desconfia ocupa dentro da PMERJ, é um dos principais instrumentos da rotina de monitoramento e controle dentro da corporação. Nesse contexto, alguns policiais têm a autoridade de denunciar. Assim, quanto maior for seu lugar, nesse arranjo desigual da PMERJ, maior será a sua credibilidade para realizar denúncias. Para acusar um oficial dentro da própria polícia, é necessário que um oficial de maior antiguidade, ou de maior posto, tenha interesse em que se faça 
a denúncia. Porém, como todos esses postos de comando são cargos de confiança e distribuídos politicamente, a legislação para punição desses policiais pode ser usada politicamente em diversos momentos (SOUZA DA SILVA, 2016).

Desse modo, como chama a atenção Nascimento (2012), o policial que erra, em geral, pode até não se incomodar tanto com a penalidade que irá receber, porque reconhece que fez algo que não deveria, contudo, fica incomodado quando sofre perseguição ou é acusado do que não fez, pois o policial sente-se agredido em sua identidade, já que fica com sua imagem "arranhada". Mesmo sabendo que, em muitos casos, é realmente responsável, ele sente-se ofendido (ou desconsiderado) quando é acusado e seu maior drama é que essa crise de reputação atinja sua honra dentro da instituição e no seu meio social (MIRANDA, 2008; BLANC JÚNIOR, 2017). Ora, o conceito de honra remete a uma desigualdade explícita, pois essa se distribui desigualmente sobre os membros da estrutura social (KANT DE LIMA, 2013).

Soma-se a isso o fato de que - mesmo antes de ser julgado - pode ser afastado do seu cargo, momento em que as acusações são, portanto, expostas publicamente. Situação como essa ocorreu com o Major Oliveira, que ficou afastado de cargos dentro da PM até o arquivamento de seu processo. Sendo assim, se as investigações realizadas na corregedoria nem sempre resultam em condenação, podem denegrir, e muito, a imagem do policial, mesmo que não fique comprovada sua participação num delito.

No caso citado acima, o juiz-auditor arquivou o processo quando a conjuntura política do estado mudou, porém, o arquivamento deixa margem sempre à possibilidade de dasarquivamento, sendo uma ameaça constante para o réu. No entanto, as normas burocráticas, que deveriam ser igualitárias, são personalisticamente distorcidas, reinventadas ou esquecidas, em benefício de grupos ligados àqueles que têm poder.

Ademais, mesmo sendo absolvido pelo Conselho Disciplinar, ou pelo Conselho de Justificação, no caso dos oficiais, ou ainda no processo militar na auditoria, o comandante geral pode simplesmente decidir punir o policial, expulsando-o da PMERJ, por questões pessoais, políticas ou para responder de forma mais rápida à imprensa, fato que não é muito incomum no estado do Rio de Janeiro. No caso dessa última, muito embora não possamos afirmar quais são os critérios que os jornalistas utilizam para selecionar os casos que trarão a público, também não podemos deixar de perceber que eles enfatizam determinados casos mais que outros. Esse posicionamento acaba cobrando respostas mais urgentes dos agentes públicos envolvidos. Por outro lado, embora não reconhecendo abertamente, os jornalistas acabam posicionando-se politicamente e procuram fazer prevalecer seus valores e ideologias (SILVA, 2010) e, muitas vezes, conseguem.

Às questões já expostas, adiciona-se o fato de a representação social ser a de que todos policiais podem estar cometendo, o tempo todo, um crime, apenas não foram pegos. Os casos que geram Conselho Especial de Justiça, para oficial superior, acabam corroborando essa ideia. Esse é o caso das punições na auditoria que, muitas vezes, são interpretadas como frutos de uma perseguição pessoal ou política, sendo utilizadas como instrumento de acusação e de defesa. É muito comum ouvir policiais 
chamando as ligações com denúncias contra eles no Disque Denúncia de "Disque Vingança”. Nesse contexto, as regras acabam não sendo internalizadas como forma legítima de controle desses agentes públicos. Assim, o que tem legitimidade é a hierarquia, essa sim, internalizada e utilizada para o controle e autocontrole desses policiais.

Com essas hierarquias o tempo todo reafirmadas, os grupos que estão no poder conseguem impor tal superioridade mesmo dentro da auditoria. Tais relações mostram-se na prerrogativa daqueles que têm o poder de conseguir fazer denúncias e mantê-las enquanto estão nos cargos de comando. Já os acusados conseguem neutralizar tais demonstrações de poder, corroborando a ideia de uma acusação injusta e podendo conseguir, inclusive, o arquivamento do processo.

Há, também, a possibilidade de o cenário político se inverter e aqueles que eram acusados tornarem-se autoridade, podendo, desta forma, influenciar nas decisões. Como me disse certa vez um juiz-auditor, quando me falava do caso do Major Oliveira: "ele foi a subcorregedor". Mesmo sem complementar a frase, ficou claro que, além da isenção, o cargo que o oficial passou a ocupar pareceu ter influenciado na decisão de arquivamento do processo.

Nesse contexto, agentes políticos acabam utilizando o sistema de justiça para impor sua autoridade dentro da corporação, deixando claro que "manda quem pode, obedece quem tem juízo!", frase ouvida de forma muito rotineira dentro da corporação, quando um policial refere-se a algum tipo de ordem recebida e cumprida a contragosto, muitas vezes, ao ser colocado para realizar seu trabalho em uma área de risco.

No entanto, a utilização dos agentes judiciários para punição desses militares estaduais não é explícita, pois o juiz-auditor, o promotor e o defensor tentam reproduzir uma imagem de isenção perante os outros agentes, principalmente aqueles ligados à Polícia Militar. Por sua vez, o juiz-auditor acaba utilizando sua superioridade hierárquica dentro do sistema de justiça - que também é hierárquico - para declarar sua decisão como mais “justa” e sem filiações a "malhas" políticas, apesar da decisão de um arquivamento, por exemplo, ser resultado de questões políticas.

Os agentes da justiça acabam fazendo uma gradação dos riscos que correm em suas decisões, para, dessa forma, administrar os conflitos de forma que todos os envolvidos no contexto não deslegitimem sua autoridade. Nessas circunstâncias, suas motivações e, até mesmo, interesses, não são explicitados, pois podem sempre dizer que estão puramente seguindo a "lei" de forma isenta e imparcial. No entanto, esses agentes também estão enredados em relações de poder, de desigualdade e de competição, escolhendo filiar-se àqueles que estão no poder, recebendo uma denúncia quando uma autoridade pede e arquivando-a quando o cenário político muda, como no caso descrito.

A autoridade, nesse sentido, como face concreta da entidade abstrata tida como Estado, cujo exercício do poder deveria realizar-se nas competências estabelecidas por lei para que fosse possível exigir suas responsabilidades, ganha uma outra configuração na sociedade brasileira. Aqui, em um lugar marcado por rígidas hierarquias, ter poder pode corresponder, na representação dos agentes, 
à suplantação das próprias leis em vigor (MIRANDA, 2012), corroborando uma tradição inquisitorial presente em nosso modelo jurídico.

A inquisitorialidade é um modelo de administração institucional de conflitos entre desiguais, pelo qual aquele que conduz o processo - sendo Estado ou não - está acima da sociedade e de seus conflitos, exercendo notável vigilância sobre conflitos entre desiguais para que não façam acusações infundadas. Em consequência disso, a eventual punição de um policial seria efeito de ter sido pego, apenas, em um erro, circunstância que pode acontecer com qualquer um. Em contrapartida a esse sistema de culpabilização, esses agentes públicos acabam avessos à qualquer forma de responsabilização. Como chama a atenção Kant de Lima (2013, p.564) a

\begin{abstract}
Responsabilização implica a liberdade de a autoridade optar pela conveniência de atuar, ou não, conforme a letra da lei, no caso concreto - princípio da oportunidade, ou discretion, em inglês - o que gera a possibilidade de controle dos agentes públicos por meio do acompanhamento, avaliação e responsabilização - accountability, em inglês - do resultado de suas opções.
\end{abstract}

Com a desigualdade jurídica formal em processos inquisitoriais, a punição deve ocorrer, preferencialmente, em relação aos outros, não havendo, nesse contexto, responsáveis e sim culpados. Enredados em relações de poder, de desigualdade e de competição, essas punições são sempre percebidas como injustas e inadequadas para o réu, que acaba não incorporando as regras legais a sua atuação prática, por não enxergar nelas formas legítimas de exercício de poder.

\title{
Considerações Finais
}

O Inquérito Policial Militar é algo que é feito pelo Estado para o próprio Estado. Nesse contexto, não podemos deixar de destacar que o Estado não existe de forma abstrata, o que existe é uma organização, um grupo de seres humanos vinculados por um sistema complexo de relações. Dentro dessa organização, uns desempenham papéis distintos e podem ter poderes ou autoridade em relação aos outros (RADCLIFFE-BROWN, 2010). Somente observando essas relações de luta e de poder é que podemos compreender as relações que produzem modelos de verdade nas práticas judiciárias (FOUCAULT, 1974).

Como vem chamando a atenção Kant de Lima (2010), no Brasil existe uma bipartição, oficial e legal, entre os profissionais da chamada justiça criminal (promotores, defensores e juízes) e os da segurança pública (policiais, agentes penitenciários, guardas municipais, bombeiros, etc). Os conflitos com suposta relevância penal, nesse sentido, devem passar, preliminarmente, pelo crivo dos funcionários do executivo - policiais militares ou civis - sob forma de um inquérito escrito e sigiloso, cujo conhecimento se reserva às autoridades competentes. Nesse momento, a produção da verdade sobre o caso ainda está nas mãos dos pares dos PMs acusados e esses realizarão o inquérito de acordo com sua "ética policial". 
Após esse primeiro crivo, o papel dos policiais que produziram o inquérito passa a ser subalterno. O que procuro trazer com o primeiro caso descrito é como essa interpretação é olhada com desconfiança quando os responsáveis pelo IPM comparecem para dar seu testemunho na auditoria. Nesse momento, os agentes da segurança pública sempre ocuparão um lugar inferior perante os demais agentes do sistema de justiça, assim, sempre terão sua versão posta à prova e, por isso, precisam convencer que suas denúncias não têm outros interesses que não estejam expostos nos documentos produzidos.

No caso dos praças, aquilo que dizem pouco influenciará no resultado final, no entanto, dará ou não confiabilidade sobre aquilo que escreveram em seus relatórios finais. Caso não passem essa confiança ao juiz-auditor (ou juízes militares, se for o caso) podem ser acusados de falso-testemunho ou falsa perícia, fato que não é incomum dentro da auditoria.

Já no caso dos oficiais, mesmo com um discurso de isenção, são levadas em conta pelos juízes também conjunturas políticas em seus processos decisórios, como procurei demonstrar no caso do Major Olivieira. Aqueles que não estão ligados diretamente ao poder executivo, como juízes e promotores, não deixarão de ter na cabeça quem são os envolvidos no caso que denunciarão e farão o julgamento segundo suas percepções.

Nesse contexto, os interesses do Estado e de seus funcionários são confundidos, fazendo com que aquele que esteja no topo da hierarquia, em nome dos interesses públicos, particularize a produção da verdade de acordo com aquilo que acha que seria a decisão mais legítima, corroborando a obediência à hierarquia como a principal forma de controle sobre o policial. Só aqueles que estão em um degrau acima na hierarquia, tendo o privilégio de confiar (ou desconfiar) dos outros envolvidos no processo, têm o poder de produzir verdades corporificadas nas decisões e sentenças dos juízes no fim do processo.

A discussão sobre o papel das testemunhas de acusação nos processos da Auditoria da Justiça Militar do Estado do Rio de Janeiro demonstra como as práticas desiguais observadas dentro das instituições do Estado também estão presentes nas práticas de controle sobre os militares estaduais. Assim, procurei demonstrar, nesse texto, como policiais que fizeram o inquérito são convocados pelo Ministério Público para participar das audiências de acusação, mas, para além de apenas construir verdade sobre o acusado, precisam, também, provar que a acusação, que resultou no inquérito que realizou, é legítima e não produto de uma injustiça causada por algum tipo de interesse particular.

Esse sistema de culpabilização, baseado em práticas inquisitoriais, não produz formas legítimas de controle e responsabilização dos militares estaduais do Estado do Rio de Janeiro, fazendo com que a hierarquia seja ratificada no meio social como a principal forma de controle desses agentes e produção de verdades jurídicas dentro da instituição. 


\section{Referências}

BLANC JÚNIOR, Maurílio Rodrigues. INQUÉRITO POLICIAL MILITAR: Existem Dois Caminhos? Trabalho de Conclusão de Curso apresentado ao Curso Especialização em Organização e Gestão de Instituições de Justiça Criminal e Segurança. Campos do Goytacazes, 2017.

BRASIL. Código Penal Militar. Decreto-Lei no 1002, de 21 de outubro de 1969. Atualizada em 31 de janeiro de 2001.

EILBAUM, Lucía. Das práticas de investigação e de produção de provas. Fazendo e Desfazendo Versões na Polícia da Província de Buenos Aires. In: KANT DE LIMA, Roberto. et al (org). Burocracias, Direitos de Conflitos. Rio de Janeiro: Garamond, 2011.

Los casos de policía en la Justicia Federal en Buenos Aires. El pez por la boca muere. Buenos Aires: Antropofagia, 2008.

FOUCAULT, Michel. Vigiar e Punir: história da violência nas prisões. Petrópolis : Editora Vozes, 2000.

A Verdade e as Formas Jurídicas. Rio de Janeiro:PUC, 1974.

GOODY, Jack. A Lógica da Escrita e a Organização da Sociedade. Lisboa: Edições 70, 1987.

KANT DE LIMA, R. Sensibilidades jurídicas, saber e poder: bases culturais de alguns aspectos do direito brasileiro em uma perspectiva comparada. Anuário Antropológico, v. 2, p. 25-51, 2011.

Entre as leis e as normas: Éticas corporativas e práticas profissionais na segurança pública e na Justiça Criminal. Dilemas: Revista de Estudos de Conflito e Controle Social - Vol. 6 - no 3 - OUT/NOV/ DEZ 2013 - pp. 549-580.

MAUSS, M. A expressão obrigatória dos sentimentos. In: Mauss, M. São Paulo: Ática,1979 [1921] p. $147-$

53. (Grandes cientistas sociais, 11)

MENDES. Regina Lúcia Teixeira. Do Princípio do Livre Convencimento Motivado. Rio de Janeiro: Lumen Juris Editora, 2012.

MIRANDA, Ana Paula Mendes de. Fisco e Cartório: Exemplos de Burocracia à Brasileira. In: LIMA, Antônio Carlos de Souza (org). Antropologia \& Direito: temas antropológicos para estudos jurídicos. Rio de Janeiro/Brasília, Contra Capa/LACED/Associação Brasileira de Antropologia, 2012.

; PITA, Maria Victoria. O que as cifras cifram?Reflexões comparativas sobre as políticas de produção de registros estatísticos criminais sobre mortes violentas nas áreas metropolitanas do Rio de Janeiro e de Buenos Aires. In: KANT DE LIMA, Roberto. et al (org). Burocracias, Direitos de Conflitos. Rio de Janeiro, Garamond, 2011.

NASCIMENTO, Andréa Ana do. Autos com e sem resistência: uma análise dos inquéritos de homicídios cometidos por policiais. Trabalho apresentado no $33^{\circ}$ Encontro Anual da ANPOCS. Caxambu, 2009.

A corrupção policial em debate: descios e impunidade nas instituições policiais do Rio de Janeiro.

Dilemas: Revista de Estudos de Conflito e Controle Social. Vol. 10, n 1 . Jan-abr de 2017. pp. 64 a 82.

RADCLIFFE-BROWN, A.R. Prefácio. IN: FORTES, M. \& E.E. EVANS-PRITCHARD, editores. Sistemas Políticos Africanos. México, Centro de Investigaciones y Estudios Superiores en Antropoligía Social. Universidad Autonoma Metropolitana: Universidad IberoAmericana, 2010, p. 43-60.

SOUZA DA SILVA, Sabrina. O "outro caso": moralidades e formas de produção de verdade em um caso de repercussão na Justiça Militar. In: KANT DE LIMA, R.; EILBAUM, L. \& MEDEIROS, F. Casos de Repercussão: perspectivas antropológicas sobre rotinas burocráticas e moralidades. 1 Ed. : Rio de Janeiro, 2017.

Disputas, intrigas e vinganças: exercícios de poder e brigas por promoção levadas à Justiça Militar do Rio de Janeiro. Confluências/revista interdisciplinar de sociologia e direito. V. 18, n 2, 2016. pp. 04-20. 
. Todos são culpados? Uma etnografia na Auditoria de Justiça Militar do Estado do Rio de Janeiro. Tese de Doutorado Apresentada ao Programa de Pós-Graduação da Universidade Fluminense. Niterói, 2013.

SILVA, Edilson Márcio Almeida da. Notícias da Violência Urbana: um estudo antropológico. Editora da Universidade Federal Fluminense: Niterói, 2010.

Recebido em 24/04/2017

Aceito em 10/10/2017 